\title{
Tuz (NaCl) Stresine Maruz Kalan Reyhan (Ocimum basilicum L.) Bitkisinde Bazı Morfolojik, Fizyolojik ve Biyokimyasal Parametreler Üzerine Salisilik Asidin Etkileri
}

\author{
Armağan KAYA ${ }^{1 *}$, Memet iNAN ${ }^{2}$ \\ ${ }^{1}$ Alanya Alaaddin Keykubat Üniversitesi, Mühendislik Fakültesi, Mühendislik Temel Bilimleri Bölümü, \\ Alanya, Antalya [ORCID ID: http://orcid.org/0000-0002-6776-3497] \\ ${ }^{2}$ Adıyaman Üniversitesi, Kahta Meslek Yüksekokulu, Bitkisel ve Hayvansal Üretim Bölümü, Adıyaman \\ [ORCID ID: http://orcid.org/0000-0001-8870-5029] \\ *Sorumlu Yazar: armagan-kaya@hotmail.com
}

Öz

Tuzluluk bitki büyüme ve gelişmesini olumsuz etkileyerek tarımsal alanlarda verim ve kaliteyi düşüren önemli bir abiyotik strestir. Bu çalışma, güzel kokusu ve uçucu yağ içeriği ile ekonomik bir değere sahip olan reyhan (Ocimum basilicum L.) bitkisinde farklı tuz konsantrasyonlarının bazı morfolojik, fizyolojik ve biyokimyasal parametreler üzerinde meydana getirdiği değişimleri belirlemek ve bu değişimler üzerine dışsal salisilik asit (SA) uygulamasının etkilerini saptamak amacı ile yapılmışır. Yapraklara SA uygulaması yapılmadan sadece $\mathrm{NaCl}$ (25 ve $50 \mathrm{mM}$ ) uygulanan bitkilerde bitki boyu, dal sayısı, taze ve kuru herba ağırlıkları, yaprakların pigment içerikleri ve antioksidan enzim aktiviteleri azalmış, buna karşın yapraklardaki malondialdehit (MDA) içeriği ve uçucu yağ oranları artmıştır. Yapraklara $0.5 \mathrm{mM} \mathrm{SA}$ uygulaması yapıldıktan sonra $\mathrm{NaCl}$ stresine maruz kalan bitkilerde ise bitki boyu, dal sayısı, taze ve kuru herba ağılıkları ile pigment içerikleri genel olarak değişmezken, MDA içeriği, uçucu yağ oranları ve antioksidan enzim aktiviteleri artmıştır. Bu çalışma, dışsal SA uygulamasının genel olarak tuz stresinin sebep olduğu olumsuz etkileri azalttı̆̆ını göstermiştir.

Anahtar Kelimeler: Tuzluluk, Salisilik asit, Ocimum basilicum, Antioksidan, Uçucu yağ

\author{
Effect of Salicylic Acid on Some Morphological, Physiological and Biochemical \\ Parameters of Basil Plant (Ocimum basilicum L.) Which was Subjected to Salt ( $\mathrm{NaCl})$ \\ Stress
}

\begin{abstract}
Salinity is an important abiotic stress which reduces the productivity and quality of agricultural areas by also negatively affecting plant growth and development. This study was conducted to determine changes on some morphological, physiological and biochemical parameters caused by different salt concentrations as well as to determine the effect of exogenous salicylic acid (SA) application on these changes for basil plant (Ocimum basilicum L.) which has an economical value due to its nice odor and essential oil content. Plant heigth, number of tree branches, fresh and dry herbal weights, pigment contents of leaves and antioxidant enzyme activities decreased for plants on which only $\mathrm{NaCl}$ ( 25 and 50 $\mathrm{mM}$ ) application was made but foliar SA application was not; while malondialdehyde (MDA) content and essential oil ratios increased on leaves of the plants. While plant heigth, number of tree branches, fresh and dry herbal weights, pigment contents of leaves did not generally change for plants which were subjected to $\mathrm{NaCl}$ stress after foliar SA application; MDA content, essential oil ratios and antioxidant enzyme activities increased. This study has shown that exogenous SA application decreased in general negative effects caused by salt stress.
\end{abstract}

Key Words: Salinity, Salicylic acid, Ocimum basilicum, Antioksidant, Essential oil 
Giriş

Tuzluluk bitki gelişimini etkileyen en önemli abiyotik stres faktörlerinden biridir. Özellikle kurak ve yarı kurak bölgelerin sulama yapılan kısımlarında ürün verimini sınırlandıran önemli bir problem haline gelmiştir. Tuzluluk osmotik stres ve iyon stresine sebep olarak bitki büyüme ve gelişmesini olumsuz etkilemekle birlikte tuzluluğun etkileri tuzun çeşidine, düzeyine, süresine ve bitkinin türüne bağlı olarak değişmektedir. Tuz stresine maruz kalan bitkiler bir takım fizyolojik, biyokimyasal ve moleküler cevaplar oluşturarak strese karşı tolerans geliştirebilirler (Çulha ve Çakırlar, 2011; Tarchoune ve ark., 2012). Literatürde tuz stresinin çeşitli bitkilerde antioksidan enzim aktivitelerini etkilediğini ve lipid peroksidasyonunu teşvik ettiğini gösteren çalışmalar mevcuttur (Bor ve ark., 2003; Tarchoune ve ark., 2010). Tuz stresi bitkilerde yapraklarda küçülme ve sayısında azalma, çiçeklenme peryodunda değişme, tohum veriminde azalmanın yanında kök gelişimini de olumsuz yönde etkilemektedir (Munns, 2003; Ashraf ve ark., 2004).

Salisilik asit (SA) bitkilerde farklı büyüme süreçleri ile ilişkili bir içsel büyüme düzenleyicisidir ve çevresel streslere karşı bitki adaptasyonunun düzenlenmesinde bir sinyal molekül olarak rol oynar. Bir bitki fenoliği olan SA, biyotik ve abiyotik streslere karşı oluşan savunma mekanizmasında rol oynadığı için içsel bir düzenleyici hormon olarak kullanılmaktadır (Baghizadeh ve Hajmohammadrezaei, 2011). Larkindale ve Knight (2002) sıcaklık stresine maruz kalan Arabidopsis bitkisinde, Kadioglu ve ark. (2011) kuraklık stresine maruz kalan Ctenanthe setosa'da, Kaya ve Yigit (2014) herbisit stresi altındaki Helianthus annuus'da, Mostofa ve ark. (2015) tuz stresine maruz kalan Oryza sativa bitkilerinde bitki savunma cevaplarının SA etkisi ile düzenlediğini rapor etmişlerdir. Kişniş (Coriandrum sativium L.) bitkisiyle yapılan bir çalışmada SA'nın $0.1 \mathrm{mM}$ düzeyine çıkarılmasıyla bitkide tohum verimiyle birlikte bitki taze herba veriminde artışların olduğu, buna karşın SA miktarının 1 $\mathrm{mM}$ düzeyine çıkarılmasıyla verimin tekrar düşmeye başladığı bildirilmektedir (Hesami ve ark.,2012).

Lamiaceae familyasına bağlı bir bitki olan reyhan (Ocimum basilicum L.) birçok ülkede yetiştirilen ve ekonomik değere sahip bir bitkidir. Bitki güzel kokusu ve içerdiği uçucu yağ bileşenleri sayesinde baharat, ilaç, gıda ve parfümeri gibi çeşitli sanayi kollarında kullanılmaktadır (Telci, 2005; Tarchoune ve ark., 2010). Bitkinin genetik yapısına ve yetiştirildiği bölgeye göre uçucu yağ oranları \% $\quad 0.26-1.71$ arasında değişim gösterebilmektedir (Telci, 2005; Wierdak, 2013; Özgen ve Arslan, 2014). Reyhan ile yapılan çalışmalarda, bitki gelişiminin, fotosentetik aktivitesinin ve antioksidan seviyesinin tuz stresinin etkisi ile değişime uğradığı bildirilmektedir (Tarchoune ve ark., 2010; Tarchoune ve ark., 2012). Ayrıca dışsal olarak uygulanan SA'nın tuz stresine maruz kalan reyhan bitkilerinde yaş-kuru ağırlık, gövde çapı, internod uzunluğu gibi bazı morfolojik parametreler ile iyon ve çözünür şeker içerikleri ve pigment seviyeleri üzerinde iyileştirici etki gösterdiği belirlenmiştir (Parizi ve ark., 2011; Mohammadzadeh ve ark., 2013; Delavari ve ark., 2014). Bununla birlikte tuz stresine bağı olarak bitkide görülen biyokimyasal değişimler ve antioksidan savunma cevapları 
ile bitkinin uçucu yağ içeriğindeki değişimler ilişkilendirilmemiştir.

Bu çalışmanın amacı, farklı iki dozda tuz stresine maruz kalan reyhan bitkisinin uçucu yağ içeriğindeki değişimleri belirleyip, bu değişimleri bitkide meydana gelen savunma cevapları ile ilişkilendirmek ve dışsal SA uygulamasının bu parametreler üzerine olan etkilerini belirlemektir.

\section{Materyal ve Metot}

Toplam Klorofil ve Karotenoid Içeriklerinin Belirlenmesi

$1 \mathrm{~g}$ yaprak dokusu $50 \mathrm{~mL}$ aseton içerisinde homojenize edilmiş ve sonra santrifüj edilmiştir. Örneklerin absorbans değerleri spektrofotometre kullanılarak 662, 645 ve 470 nm dalga boylarında ölçülmüştür (De Kok ve Graham 1980; Lichtenthaler ve Welburn 1983).

\section{Lipid Peroksidasyonu}

$0.5 \mathrm{~g}$ yaprak dokusu \% $0.1^{\prime}$ lik trikloroasetik asit (TCA) içinde homojenize edilmiş ve homojenat $10.000 \mathrm{rpm}$ 'de santrifüj edilmiştir. Bu solüsyonun $2 \mathrm{~mL}$ 'sine, $2 \mathrm{~mL} \% 0.5^{\prime}$ lik thiobarbiturik asit (TBA) eklenip karışım 30 dakika $95^{\circ} \mathrm{C}^{\prime}$ de su banyosunda kaynatılmıştır (TBA \% 20'lik TCA içerisinde hazırlanmıştır). Daha sonra örnekler buz banyosunda soğutulmuştur. Soğutulan karışım tekrar 10.000 rpm'de santrifüj edilmiştir. Süpernatantın absorbansı $532 \mathrm{~nm}$ ve $600 \mathrm{~nm}$ 'de ölçülmüştür (Heath ve Packer, 1968).

\section{Enzim Aktivitesi Tayini}

$0.5 \mathrm{~g}$ yaprak $10 \mathrm{~mL} 50 \mathrm{mM}$ ( $\mathrm{pH} 7.6$ ) fosfat tamponunda homojenize edilmiş ve homojenat $20 \mathrm{dk} 15000 \mathrm{rpm}$ de santrifüj edilmiştir. Süpernatan okuma yapılıncaya kadar $-80^{\circ} \mathrm{C}$ derin dondurucuda saklanmıştır. Askorbat peroksidaz (APX) aktivitesi için reaksiyon karışımı $550 \mu \mathrm{L} 50 \mathrm{mM}$ fosfat tamponu, $100 \mu \mathrm{L} 10 \mathrm{mM}$ EDTA $(12 \mathrm{mM}$ $\mathrm{H}_{2} \mathrm{O}_{2}$ 'de hazırlandı) ve $250 \mu \mathrm{L}$ bitki ekstraktından oluşturulmuştur ve spektrofotometre kullanılarak $290 \mathrm{~nm}$ 'de absorbans değişimi belirlenmiştir (Nakano ve Asada, 1981; Cakmak, 1994). Peroksidaz (POD) aktivitesi için reaksiyon karışımı $3 \mathrm{~mL}$ $0.1 \mathrm{M}$ fosfat tampon, $400 \mu \mathrm{L} 0.03 \mathrm{M} \mathrm{H}_{2} \mathrm{O}_{2}$, $500 \mu \mathrm{L} 0.2 \mathrm{M}$ guaiacol ve $100 \mu \mathrm{L}$ ekstrakt eklenerek hazırlanmış ve absorbans değişimi spektrofotometre kullanılarak 436 nm'de belirlenmiştir (Mac Adam ve ark., 1992). Enzim aktiviteleri spesifik aktivite olarak ifade edilmiştir.

\section{Bitki Gelişimi ve Uygulamalar}

$\mathrm{Bu}$ araştırmada bitki materyali olarak yerel popülasyondan temin edilen tohumların, çimlendirilmesinden elde edilen reyhan (Ocimum basilicum L.) fideleri kullanılmıştır. Bu amaçla tohumlar torf ve perlit (3:1) içeren 7 litrelik $(28 \times 22,5 \mathrm{~cm}$ ebatlarında) saksılara her bir uygulama için dört tekrarlamalı olacak şekilde ekilmiş, $30^{\circ} \mathrm{C}$ sıcaklık ve \% 65 nem koşullarına sahip iklim odasına 09 Ekim 2015 tarihinde yerleştirilmiştir. Bitkilerde ilk çıkışlar dördüncü günde başlamıştır. Kök gelişimi tamamlandıktan sonra fidelerin $20-25 \mathrm{~cm}$ ve 10- 12 yapraklı olduğu dönemde, saksıların yarısında 0.5 mM SA (\%0.02 Tween 20 içinde hazırlandı) tüm bitki yapraklarına aynı oranda püskürtme yolu ile bir defa uygulanmıştır. Saksıların diğer yarısında ise SA uygulaması yapılmadan sadece \%0.02 Tween 20 çözeltisi yapraklara püskürtülmüştür. Yapraklara dışsal SA 
uygulamasından iki gün sonra hem $\mathrm{SA}$

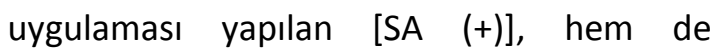
yapılmayan [SA (-)] bitkiler haftada üç kez 25 ve $50 \mathrm{mM}$ konsantrasyonlarda hazırlanan 150 mL'lik $\mathrm{NaCl}$ çözeltileri ile sulanmış ve uygulamanın 20. gününde, bitkilerin tam çiçeklenme döneminden sonra toplanan bitki yaprakları analiz edilmek üzere $-80{ }^{\circ} \mathrm{C}^{\prime} \mathrm{de}$ saklanmıştır.

\section{Uçucu Yağ Oranı}

Uygulamaya tabi tutulan ve kontrol amacıyla yetiştirilen bitkiler çiçeklenme döneminden sonra, 08 Ocak 2016 tarihinde, hasat edilip her bir uygulama için $30 \mathrm{~g}$ kuru yaprak örnekleri alınmış ve bu kuru yapraklar clevenger tipi uçucu yağ cihazında, su buharı distilasyonu yöntemine göre 3 saat boyunca ekstraksyona tabi tutulmuş, volumetrik olarak ölçümler yapıldıktan sonra uçucu yağ oranları \% olarak belirlenmiştir.

\section{Istatistiksel Analizler}

Elde edilen sonuçlar, tesadüf blokları deneme desenine göre SPSS 17.0 paket programında istatistiki analize tabi tutulmuş, ortalamalar arasındaki farklılıklar Duncan's (1955) ve bağımsız " $t$ " testleri kullanılarak belirlenmiştir. Analizlerde $p<0.05$ istatistiksel olarak önemli kabul edilmiştir.

\section{Araştırma Bulguları ve Tartışma}

\section{Toplam Klorofil ve Karotenoid Içerikleri}

Yapraklarda klorofil içeriğindeki değişimler bitkinin direnci ve çevre kalitesinin önemli bir göstergesi olarak rol oynar (Carter ve Spiering, 2002). Khaliq ve ark. (2014), artan konsantrasyonlarda $\mathrm{NaCl}$ stresine maruz kalan üç farklı reyhan ekotipinde, toplam klorofil içeriklerinin, özellikle yüksek tuz konsantrasyonlarında azaldığını bildirmişlerdir. Delavari ve ark. (2014) 100 ve $200 \mathrm{mM} \mathrm{NaCl}$ stresine maruz kalan reyhanda fotosentetik pigmentlerin kontrole kıyasla azaldığını belirtmiş ve çimlenme öncesi tohumları 0.01 ve $0.1 \mathrm{mM}$ SA çözeltisinde şişirilen bitkilerde ise pigment içeriğinin SA uygulanmayan bitkilere kıyasla genel olarak daha yüksek olduğunu rapor etmiştir. Bu çalışmada SA uygulaması yapılan bitkilerde [SA (+)] en yüksek toplam klorofil içeriği $12.81 \mathrm{\mu g} \mathrm{g}^{-1}$ olarak $25 \mathrm{mM}$ stres grubunda bulunmakla birlikte bu değer kontrol ve $50 \mathrm{mM}$ uygulama grubundan istatistiksel anlamda farklı değildir ( $p$ [ 0.05 . Yapraklara SA uygulaması yapılmayan bitkilerde [SA (-)] ise toplam klorofil içeriği kontrol ve $25 \mathrm{mM}$ stres grubunda istatistiksel anlamda aynı iken $50 \mathrm{mM}$ stres grubunda azalmıştır (p] 0.05). Bu azalış klorofil yıkımının artışından kaynaklanabilir. Santos (2004), tuz stresine maruz kalan ayçiçeğinde klorofil yıkımından sorumlu klorofillaz enziminin 15. güne kadar arttığını ve buna bağlı olarak da klorofil içeriğinin azaldığını belirtmiş̧ir. Yapraklara SA uygulanması kontrol ve $25 \mathrm{mM}$ stres gruplarında toplam klorofil içeriğinde bir değişime sebep olmazken $50 \mathrm{mM}$ stres grubunda toplam klorofil içeriğini arttırmış ve bu artış istatistiksel olarak anlamlı bulunmuştur ( $p$ 回 0.05 (Şekil 1). En yüksek karotenoid içeriği SA (+) bitkilerde $2.81 \mu \mathrm{g} \mathrm{g}^{-1}$ olarak 25 $\mathrm{mM}$ stres grubunda bulunmakla birlikte bu değer kontrol ve $50 \mathrm{mM}$ stres grubundan istatistiksel anlamda farklı değildir ( $p$ 回 0.05 . SA (-) bitkilerde ise karotenoid içeriği kontrole kıyasla stres gruplarında artış göstermiş ve en yüksek karotenoid içeriği $2.39 \mu \mathrm{g} \mathrm{g}^{-1}$ olarak $50 \mathrm{mM}$ stres grubunda belirlenmiştir. Dışsal SA uygulaması kontrol 
ve stres gruplarında karotenoid içeriğini SA uygulanmayan bitkilere kıyasla arttırmıştır (Şekil 1). Karotenoidler bitkilerde oksidatif hasara karşı koruyucu bir rol oynarlar (Li ve ark., 2010). Bu nedenle bu çalışmada SA (-) bitkilerde karotenoid içeriği kontrole kıyasla artarken SA (+) bitkilerde karotenoid içeriği kontrol grubu ve stres grupları arasında önemli bir değişim göstermemiştir. Bunun sebebi dışsal SA uygulamasının bitkilerde stresin sebep olduğu hasarı azaltması ile ilişkili olabilir.

\section{Lipid Peroksidasyonu}

Lipid peroksidasyonunun son ürünü olan MDA oksidatif hasarın önemli biyobelirteçlerinden biridir. Literatürde çeşitli stres şartlarına maruz kalan bitkilerde MDA içeriği arttığını gösteren çalışmalar mevcuttur (Qiu ve ark., 2014; Qing ve ark., 2015; Kaya ve Doganlar, 2016). Tarchoune ve ark. (2010) birbirine eşdeğer konsantrasyonda $\mathrm{NaCl}$ ve $\mathrm{Na}_{2} \mathrm{SO}_{4}$ uygulanan reyhanda kontrol ve stres grupları arasında lipid peroksidasyon seviyesinin değişmediğini belirtmiştir. Buna karşın Delavari ve ark. (2010 ve 2014), reyhanın kök ve sürgünlerinde artan $\mathrm{NaCl}$ konsantrasyonuna bağlı olarak MDA içeriğinin arttığını ve çimlenme öncesi tohumları 0.01 ve $0.1 \mathrm{mM}$ SA çözeltisinde şişirilen bitkilerde MDA içeriğinin SA uygulanmayan bitkilere kıyasla özellikle stres gruplarında daha düşük seviyelerde olduğunu rapor etmiştir. Bizim çalışmamızda da bu bulgulara benzer olarak hem SA (+) hem de SA (-) bitkilerde MDA içeriği stres gruplarında kontrole kıyasla artmış ve en yüksek MDA içeriği sırası ile 4.76

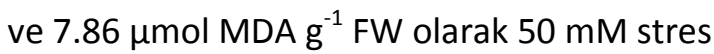
grubunda bulunmuştur. SA (+) bitkilerde kontrol ve stres gruplarında MDA içeriği SA (-
) bitkilere kıyasla daha düşük seviyelerde belirlenmiş ve bu fark istatistiksel olarak anlamlı bulunmuştur ( $p$ [ 0.05 (Şekil 2). Bu durum dışsal SA uygulamasının çeşitli yollarla oksidatif stresi azaltmasından kaynaklanabilir.

\section{Enzim Aktiviteleri}

Antioksidan enzimler stres etkisiyle üretilen reaktif oksijen türlerini temizleyerek bitkinin stresle başa çıkmasını sağlar. POD ve APX önemli antioksidan enzimlerden olup, ortamda biriken $\mathrm{H}_{2} \mathrm{O}_{2}^{\prime}$ yi temizleyerek bitki stresini azaltmada rol oynarlar.

Tarchoune ve ark. (2010) eşdeğer seviyede $\mathrm{NaCl}$ ve $\mathrm{Na}_{2} \mathrm{SO}_{4}$ uygulanan reyhanda $\mathrm{POD}$ ve APX seviyelerinin 30. günde kontrole kıyasla arttığını bildirmiştir. Yapılan bu çalışmada ise SA(-) bitkilerde POD ve APX aktiviteleri kontrole kıyasla stres gruplarında azalırken $\mathrm{SA}(+)$ bitkilerde kontrole kıyasla stres gruplarında artmıştır ( $p$ ? 0.05 (Şekil 2). Dışsal SA uygulaması aynı konsantrasyonda tuz stresine maruz kalan bitkilerde POD aktivitesi üzerinde önemli bir etki göstermezken APX aktivitesini arttırdı (p] 0.05 (Şekil 2). Bizim çalışmamızda SA (-) bitkilerde tuz stresinin etkisi ile her iki enzim aktivitesindeki azalmanın sebebi ortamda reaktif oksijen türlerinin (ROS) aşırı birikimi olabilir. Nitekim Jiang ve Yang (2009) stres altındaki bitkilerde aşırı ROS birikimi sonucu özelikle katalaz ve peroksidaz enzimlerinin aktivitesinin engellenebileceğini rapor etmiştir. Bununla birlikte $\mathrm{SA}(+)$ bitkilerde stres gruplarındaki enzim aktiviteleri kontrole kıyasla artmıştır. Bu artış ile uyumlu olarak Hayat ve ark. (2010) dışsal SA uygulamasının özellikle stres altındaki bitkilerde antioksidan enzim aktivitesini arttırdığını belirtmiştir. 


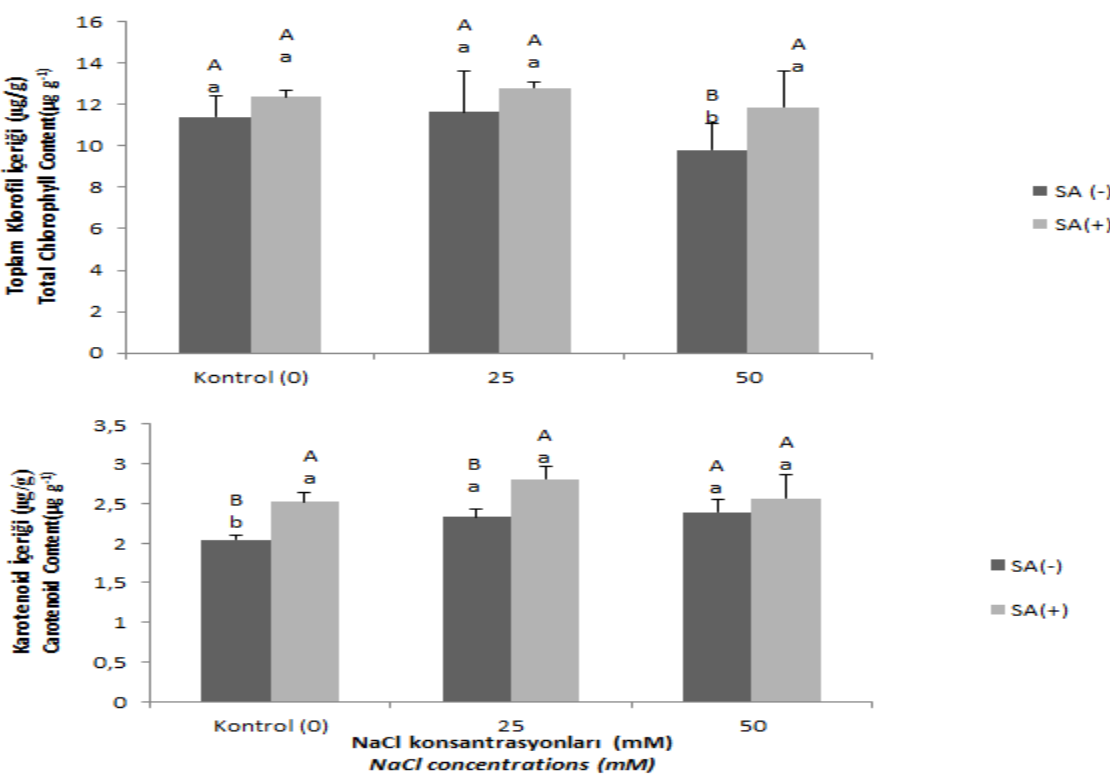

Şekil 1. Farklı $\mathrm{NaCl}$ Konsantrasyonları ve Salisilik Asit Uygulamalarının Toplam Klorofil ve Karotenoid İçerikleri Üzerine Etkileri. Farklı Küçük Harfler $\mathrm{NaCl}$ 'nin Farklı Konsantrasyonları Arasındaki Önemli Farklılıkları Duncan Testine Göre ( $p$ [ 0.05 Gösterirken, Farklı Büyük Harfler Her Bir $\mathrm{NaCl}$ Konsantrasyonunda $\mathrm{SA}(+)$ ve $\mathrm{SA}(-)$ Grupları Arasındaki Önemli Farkı Bağımsız " $t$ " Testine Göre ( $p$ [ 0.0\$1fade Eder

Figure 1. Effects of Different $\mathrm{NaCl}$ Concentrations and Salisilic Acid Applications on Total Chlorophyl and Carotenoid Contents. The Different Lower-Case Letters are Significantly Different From Each Other ( $p$ [ 0.05) Among Different Concentration of $\mathrm{NaCl}$ According to Duncan's Test. The Different Upper-Case Letters are Significantly Different Among Groups $S A(+)$ and $S A(-)$ (p! 0.05) For Each Concentration of $\mathrm{NaCl}$ According to Independet Samples " $t$ " Test

\section{Bitki Gelişimi}

Reyhan bitkisine farklı tuz ve salisilik asit uygulamaları sonucu, bitki başına düşen bitki boyu, dal sayısı, taze ve kuru herba verimleri ile uçucu yağ oranlarına ilişkin değerler Tablo 1.'de verilmiştir.

\section{Bitki Boyu}

Salisilik asit uygulanan ve uygulanmayan saksılardan elde edilen bitki boyu değerleri ele alındığında, SA uygulamasının bitki boyu üzerine olumlu etki yaptığı, buna karşın tuz konsantrasyonlarının artmasıyla birlikte bitki boylarında bir azalma olduğu belirlenmiştir. $S A(-)$ ve $S A(+)$ bitkilerde en yüksek bitki boyları kontrol gruplarında sırasıyla 40.66 ve $43.25 \mathrm{~cm}$ olarak, en düşük bitki boyları ise 50
mM stres grubunda 28.25 ve $39.16 \mathrm{~cm}$ olarak tespit edilmiştir (Tablo 1). Bu sonuçlar SA uygulamalarının, stres koşullarında yetişen bitkilerde morfolojik özellikleri iyileştirici etki yaptığını bildiren diğer araştırıcıların (Hayat ve ark., 2010; Parizi ve ark., 2011; Mohammadzadeh ve ark., 2013; Delavari ve ark., 2014) bildirdikleri bulguları destekler niteliktedir.

\section{Dal Sayısı}

Bitki boyu değerlerinde olduğu gibi, bitki başına düşen dal sayıları da hem SA hem de tuz uygulamalarından önemli derecede etkilenmiştir. $\mathrm{SA}(+)$ bitkilerden elde edilen ortalama dal sayısı değeri 7.13 adet/bitki olurken, SA(-) bitkilerden elde edilen 
ortalama bitki boyu değeri 6.00 adet/bitki olmuştur. Tuz konsantrasyonları arttıkça bitkilerde daha az dal oluştuğu belirlenmiştir. Hem SA(-) hem SA(+) bitkilerde en yüksek dal sayısı sırasıyla 7.33 adet/bitki ve 8.41 adet/bitki olarak kontrol gruplarında ölçülmüştür (Tablo 1). SA uygulamasının bitkilerde strese bağlı olumsuzlukları kısmen engellediği ve bitki gelişimini olumlu yönde etkilediği bazı araştırıcılar tarafından bildirilmektedir (Baghizadeh ve Hajmohammadrezaei, 2011; Larkindale ve Knight, 2002).

\section{Taze ve Kuru Herba Verimleri}

Bitki başına düşen en yüksek taze herba verimi (13.87 g/bitki) SA(+) bitkilerde $25 \mathrm{mM}$ tuz konsantrasyonu uygulanan saksılarda belirlenmiştir. SA uygulanmayan saksılarda bitki başına ortalama olarak $10.86 \mathrm{~g}$, SA uygulanan saksılarda ise $12.33 \mathrm{~g}$ taze herba alınmıştır. SA(-) gruplarda, tuz konsantrasyonunun artmasıyla birlikte bitki başına düşen taze herba verimleri azalmış ve en düşük taze herba verimi $9.64 \mathrm{~g} /$ bitki olarak $50 \mathrm{mM}$ tuz konsantrasyonunda belirlenmiştir. SA(+) gruplarda ise kontrol ve $25 \mathrm{mM}$ düzeyindeki tuz konsantrasyonu uygulanan saksılardan elde edilen taze herba verimleri, farklı olmakla birlikte istatistiki anlamda önemli farklııkların olmadığı belirlenmiştir. Bitki başına düşen kuru herba verimleri incelendiğinde $\mathrm{SA}(-)$ bitkilerde en yüksek değer kontrol grubunda ( $2.07 \mathrm{~g} / \mathrm{bitki})$, en düşük değer ise $50 \mathrm{mM}$ tuz konsantrasyonu uygulanan saksılardan elde edilmiştir (1.80 g/bitki). SA(+) bitkilerde stres ve kontrol grupları arasında istatistiki anlamda önemli farklılıklar oluşmamıştır (Tablo 1). Bu durum muhtemelen SA'nın tuzdan kaynaklı stres etkisini azaltmasından meydana gelmiştir. Bazı araştırııılar da bulgularımıza benzer şekilde, tuz stresinin bitkilerde taze, kuru herba ve tohum verimlerinin yanında kök gelişimlerini de olumsuz yönde etkilediğini bildirmektedirler (Munns, 2003; Ashraf ve ark., 2004).

\section{Uçucu Yağ Oranı}

Uygulamalardan elde edilen kuru yapraklardaki uçucu yağ oranları incelendiğinde, $\mathrm{SA}(+)$ ve $\mathrm{SA}(-)$ bitkiler arasında istatistiksel anlamdaki farklıııkların önemli olmadığı belirlenmiştir. SA(-) uygulamalarında kuru yapraklardaki uçucu yağ oranı ortalama \% $1.28, \mathrm{SA}(+)$ uygulamalarında ise $\% \quad 1.30$ olarak belirlenmiştir. $\mathrm{SA}(+)$ ve $\mathrm{SA}(-)$ bitkilerde tuz konsantrasyonu arttıkça uçucu yağ oranlarında artışların olduğu görülmüştür. En yüksek uçucu yağ oranı $\mathrm{SA}(+)$ bitkilerde 50 $\mathrm{mM}$ tuz uygulamasından elde edilirken (\% 1.39), kontrol gruplarında oran \% 1.22 olarak belirlenmiştir. Benzer şekilde SA(-) grubunda en yüksek uçucu yağ oranı yine $50 \mathrm{mM}$ tuz konsantrasyonunda (\% 1.33), en düşük uçucu yağ oranı ise kontrol bitkilerinde (\% 1.24) tespit edilmiştir. Reyhan yapraklarındaki uçucu yağ oranı bitkinin genetik yapısına, yetiştirildiği bölgeye ve şartlarına göre \% 0.26- $\quad 1.71$ arasında değişim gösterebilmektedir (Telci, 2005; Wierdak, 2013; Özgen ve Arslan, 2014). Saptadığımız değerler bildirilen bu değerler arasında olmuştur. Uygulanan tuz konsantrasyonları uçucu yağ oranlarını önemli derecede etkilemiştir. Morales ve ark. (1993) tuz stresinin bitkilerdeki uçucu yağ gibi ikincil metabolitlerin üretimini arttırırken, birincil metabolitlerinin azalmasına neden olabileceğini bildirmektedirler. Sonuçlarımız araştırıcıların bildirmiş oldukları bulguları destekler niteliktedir. 

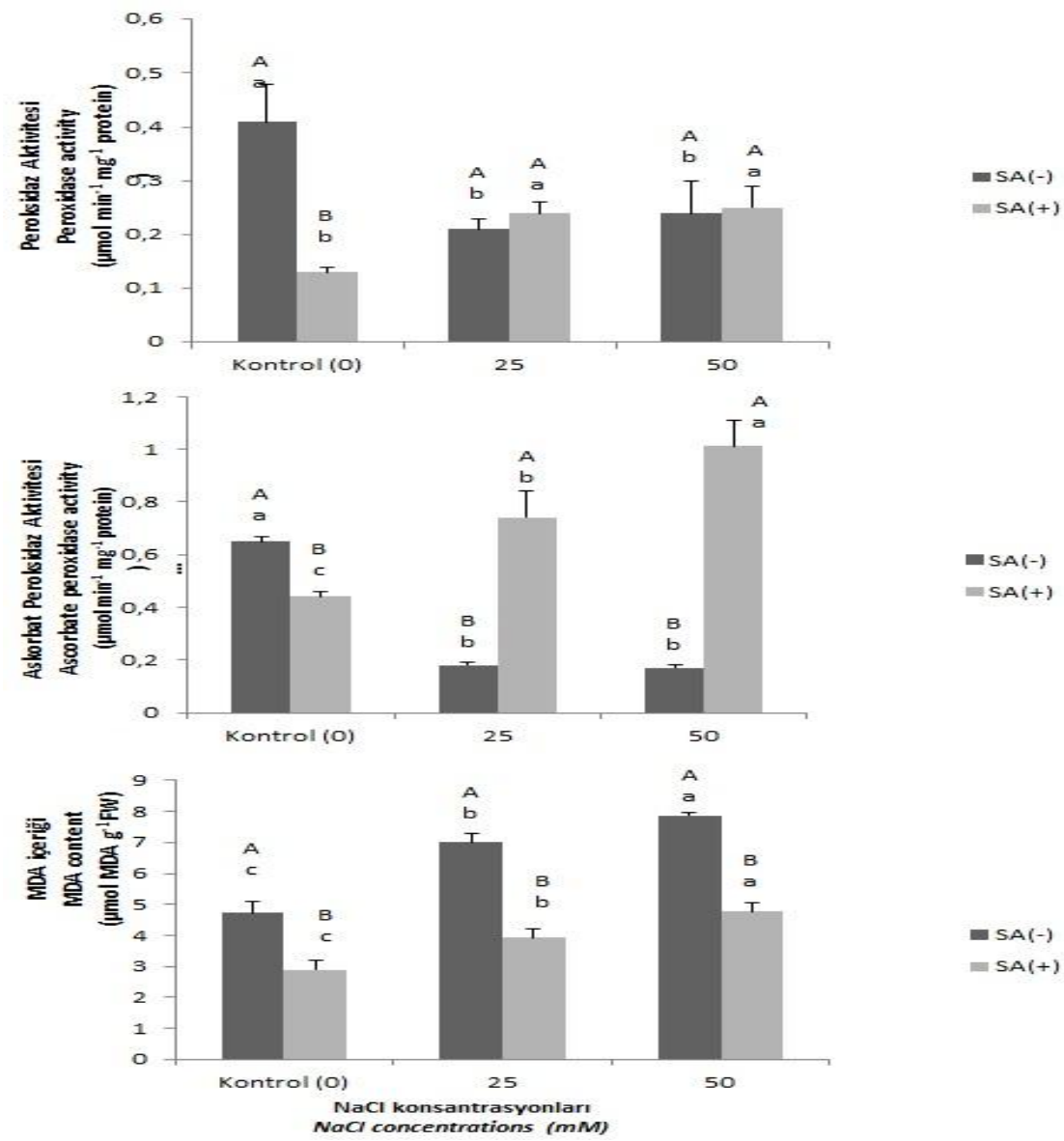

Şekil 2. Farklı $\mathrm{NaCl}$ Konsantrasyonları ve Salisilik Asit Uygulamalarının Malondialdehit (MDA) İçeriği ile Peroksidaz (POD) ve Askorbat Peroksidaz (APX) Aktiviteleri Üzerine Etkileri. Farklı Küçük Harfler NaCl'nin Farklı Konsantrasyonları Arasındaki Önemli Farklııkları Duncan Testine Göre ( $p$ [ 0.05 Gösterirken, Farklı Büyük Harfler Her Bir $\mathrm{NaCl}$ Konsantrasyonunda $\mathrm{SA}(+)$ ve SA(-) Grupları Arasındaki Önemli Farkı Bağımsız " $t$ " Testine Göre ( $p$ ? 0.0\$1 ifade Eder

Figure 2. Effects of Different $\mathrm{NaCl}$ Concentrations and Salisilic Acid Applications on Malondialdehyde (MDA) Content and Peroxidase (POD) and Ascorbate Peroxidase (APX) Activities. The Different Lower-Case Letters are Significantly Different From Each Other ( $p$ [ 0.05) Among Different Concentroion of NaCl According to Duncan's Test. The Different Upper-Case Letters are Significantly Different Among Groups SA(+) and SA(-) (PQ] 0.05) For Each Concentration of $\mathrm{NaCl}$ According to Independet Samples " $t$ " Test 
Çizelge 1*. Farklı NaCl Konsantrasyonları ve Salisilik Asit Uygulamalarının Bitki Boyu, Dal Sayısı, Taze ve Kuru Herba Verimi ve Uçucu Yağ Oranları Üzerine Etkileri

Table 1*. Effects Of Different $\mathrm{NaCl}$ Concentrations and Salisilic Acid Applications on Plant Height, Number of Plant Branches, Fresh and Dry Herba Yield and Essential Oil Content

\begin{tabular}{|c|c|c|c|c|c|c|}
\hline \multicolumn{2}{|c|}{$\begin{array}{l}\text { Gruplar } \\
\text { (Groups) }\end{array}$} & $\begin{array}{l}\text { Bitki Boyu } \\
\text { Plant heigth } \\
\text { (cm) }\end{array}$ & $\begin{array}{l}\text { Dal Sayısı } \\
\text { (adet/bitki) } \\
\text { Number of } \\
\text { branches } \\
\text { (number/plant) }\end{array}$ & $\begin{array}{l}\text { Taze Herba } \\
\text { (g/bitki) } \\
\text { Fresh herb } \\
\text { yield } \\
\text { (g/plant) }\end{array}$ & $\begin{array}{l}\text { Kuru Herba } \\
\text { (g/bitki) } \\
\text { Dry herb yield } \\
\text { (g/plant) }\end{array}$ & $\begin{array}{l}\text { Uçucu Yağ } \\
\text { İçeriği } \\
\text { Essential oil } \\
\text { content } \\
\text { (\%) }\end{array}$ \\
\hline \multirow[t]{3}{*}{ SA(-) } & $\begin{array}{c}\text { Kontrol } \\
(0)\end{array}$ & $\mathrm{B} 40.66 \pm 0.28 \mathrm{a}$ & A7.33 $\pm 0.57 a$ & A12.09 $\pm 0.34 a$ & $\mathrm{~A} 2.07 \pm 0.02 \mathrm{a}$ & $\mathrm{A} 1.24 \pm 0.01 \mathrm{c}$ \\
\hline & $\begin{array}{l}25 \mathrm{mM} \\
(\mathrm{NaCl})\end{array}$ & B33.00 $\pm 2.64 b$ & $A 5.66 \pm 0.57 b$ & $\mathrm{~B} 10.84 \pm 0.13 b$ & $A 1.96 \pm 0.05 b$ & $\mathrm{~A} 1.27 \pm 0.01 \mathrm{~b}$ \\
\hline & $\begin{array}{l}50 \mathrm{mM} \\
(\mathrm{NaCl})\end{array}$ & $\mathrm{B} 28.25 \pm 3.73 \mathrm{~b}$ & B5.00 $\pm 1.00 \mathrm{~b}$ & B9.64 $\pm 0.09 c$ & $\mathrm{~B} 1.80 \pm 0.005 \mathrm{c}$ & $A 1.33 \pm 0.01 a$ \\
\hline \multicolumn{2}{|c|}{$\begin{array}{c}\text { Ortalamalar } \\
\text { (Averages) }\end{array}$} & 33.97 & 6.00 & 10.86 & 1.94 & 1.28 \\
\hline \multirow[t]{3}{*}{$\mathrm{SA}(+)$} & $\begin{array}{c}\text { Kontrol } \\
(0)\end{array}$ & A43.25 $\pm 1.08 a$ & $A 8.41 \pm 0.52 a$ & A12.12 $\pm 0.63 a$ & $\mathrm{~A} 2.09 \pm 0.07 \mathrm{a}$ & $\mathrm{A} 1.22 \pm 0.01 \mathrm{c}$ \\
\hline & $\begin{array}{l}25 \mathrm{mM} \\
(\mathrm{NaCl}) \\
\end{array}$ & $\mathrm{A} 42.08 \pm 3.00 \mathrm{a}$ & A8.16 $\pm 1.04 b$ & A13.87 $\pm 0.60 a$ & $\mathrm{~A} 2.39 \pm 0.32 \mathrm{a}$ & $\mathrm{A} 1.28 \pm 0.005 \mathrm{~b}$ \\
\hline & $\begin{array}{l}50 \mathrm{mM} \\
(\mathrm{NaCl})\end{array}$ & A39.16 $\pm 6.00 a$ & A7.83 $\pm 0.28 a$ & $A 11.01 \pm 0.62 b$ & $\mathrm{~A} 2.03 \pm 0.01 \mathrm{a}$ & $A 1.39 \pm 0.01 a$ \\
\hline \multicolumn{2}{|c|}{$\begin{array}{l}\text { Ortalamalar } \\
\text { (Averages) }\end{array}$} & 41.50 & 7.13 & 12.33 & 2.17 & 1.30 \\
\hline
\end{tabular}

* Farklı Küçük Harfler NaCl'nin Farklı Konsantrasyonları Arasındaki Önemli Farklılıkları Duncan Testine Göre ( $p$ ? 0.05 Gösterirken, Farklı Büyük Harfler Her Bir NaCl Konsantrasyonunda SA(+) ve SA(-) Grupları Arasındaki Önemli Farkı Bağımsız " $t$ ” Testine Göre ( $p$ ? 0.05 ifade Eder.

*The Different Lower-Case Letters are Significantly Different From Each Other ( $p$ [0.05) Among Different Concetration of NaCl According to Duncan's Test. The Different Upper-Case Letters are Significantly Different Among Groups SA(+) and SA(-) (p? 0.05) For Each Concentration of $\mathrm{NaCl}$ According to Independet Samples " $t$ " Test.

\section{Sonuçlar}

Reyhan bitkisine uygulanan tuz konsantrasyonları genel olarak bitkinin büyüme ve gelişmesini olumsuz yönde etkilemiştir. Tuz stresine maruz kalan reyhanda bitki boyu, dal sayısı, taze ve kuru herba ağırlıkları ile pigment içerikleri belirgin biçimde azalmış, buna karşın oksidatif hasarın önemli bir belirteci olan MDA içeriği ise artmıştır. Ayrıca stres altında seviyesi arttığı bilinen uçucu yağ içeriği ise tuz konsantrasyonunun artışına paralel olarak artmıştır. Bununla birlikte MDA ve uçucu yağ içeriğinde artışı teşvik eden stres koşulları $P O D$ ve $A P X$ aktivitelerinin baskılanmasına sebep olmuştur. Çalışmada yapraklara SA uygulanması, uçucu yağ içeriği üzerinde önemli bir değişime sebep olmazken, tuzluluğun etkisi ile diğer parametrelerde görülen olumsuz etkileri genel olarak iyileştirmiştir. Bu çalışma, reyhan bitkisinde, SA uygulamasının genel olarak tuz stresinin sebep olduğu olumsuz etkileri azalttığını göstermektedir. 


\section{Kaynaklar}

Ashraf, M., Mukhtar, N., Rehman, S., Rha, E.S., 2004. Salt-induced changes in photosynthetic activity and growth in a potential medicinal plant Bishops weed (Ammi majus L). Photosynthetica. 42 (4): 543-550.

Baghizadeh, A., Hajmohammadrezaei, M., 2011. Effect of drought stress and its interaction with ascorbate and salicylic acid on okra (Hibiscus esculents L.) germination and seedling growth. The Journal of Stress Physiology \& Biochemistry. 7(1): 55-65.

Bor, M., Özdemir, F., Türkan, I., 2003. The effect of salt stress on lipid peroxidation and antioxidants in leaves of sugar beet Beta vulgaris $\mathrm{L}$. and wild beet Beta maritima $\mathrm{L}$. Plant Science. 164: 77-84.

Cakmak, I., 1994. Activity of ascorbate-dependent $\mathrm{H}_{2} \mathrm{O}_{2}$-scavenging enzymes and leaf chlorosis are enhanced in magnesiumdeficient and potassium deficient leaves, but not in phosphorus-deficient leaves. The Journal of Experimental Botany. 45: 1259-1266.

Carter, A.G., Spiering, B.A., 2002. Optical properties of intact leaves for estimating chlorophyll concentration. Journal of Environmental Quality. 31: 1424-1432.

Çulha, Ş., Çakırlar, H., 2011. Tuzluluğun Bitkiler Üzerine Etkileri ve Tuz Tolerans Mekanizmaları, Afyon Kocatepe Üniversitesi Fen Bilimleri Dergisi. 11:11-34.

De-Kok, L., Graham, M., 1980. Levels of pigments, soluble proteins, amino acids and sulfhydryl compounds in foliar tissue of Arabidopsis thaliana during dark induced and natural senescence. Plant Physiology and Biochemistry. 27: 133-142.

Delavari, M., Enteshari, S., Manoochehri Kalantari, K., 2014. Effects of Response of Ocimum basilicum to the interactive effect of salicylic acid and salinity stress, Iranian Journal of Plant Physiology, 4(2):983-990.

Delavari, P.M., Baghizadeh, A., Enteshari, S.H., Kalantari, Kh.M., Yazdanpanah, A., Mousavi, E.A., 2010. The Effects of Salicylic Acid on Some of Biochemical and Morphological Characteristic of Ocimum Basilicucm under Salinity Stress. Australian
Journal of Basic and Applied Sciences, 4(10): 4832-4845.

Duncan, D.B., 1955. Multiple range and multiple $F$ test sbiometrics. Int. Biom. Soc. 11(1):142.

Hayat, Q., Hayat, S., Irfan, M., Ahmad, A., 2010. Effect of exogenous salicylic acid under changing environment: A review. Environmental and Experimental Botany. 68: 14-25.

Heath, R.L., Packer, L., 1968. Photoperoxidation in isolated chloroplast, I. kinetics and stoichiometry of fatty acid peroxidation. Archives of Biochemistry and Biophysics. 125: 180-198.

Hesami, S., Nabizadeh, E., Rahimi, A., Rokhzadi, A., 2012. Effects of salicylic acid levels and irrigation intervals on growth and yield of coriander (Coriandrum sativum) in field conditions, Environmental and Experimental Biology 10: 113-116.

Jiang, L., Yang, H., 2009. Prometryne-induced oxidative stress and impact on antioxidant enzymes in wheat. Ecotoxicology and Environmental Safety. 72 (6):1687-1693.

Kadioglu, A., Saruhan, N., Sağlam, A., Terzi, R., Acet, T., 2011. Exogenous salicylic acid alleviates effects of long term drought stress and delays leaf rolling by inducing antioxidant system. Plant Growth Regulation. 64: 27-37.

Kaya, A., Doganlar, Z.B., 2016. Exogenous jasmonic acid induces stress tolerance in tobacco (Nicotiana tabacum) exposed to imazapic. Ecotoxicology and Environmental Safety 124:470-479.

Kaya, A., Yigit, E., 2014. The physiological and biochemical effects of salicylic acid on sunflowers (Helianthus annuus) exposed to flurochloridone. Ecotoxicology and Environmental Safety. 106: 232-238.

Khaliq, S., Zafar, Z.U., Athar, H.R., Khaliq, R., 2014. Physiological and biochemical basis of salt tolerance in Ocimum basilicum L. Journal of Medicinal Plants Studies. 2(1): 18-27.

Larkindale, J., Knight, M., 2002. Protection against heat stress-induced oxidative damage in Arabidopsis involves calcium, abscisic acid, ethylene, and salicylic acid. Plant Physiology. 128: 682-695.

Li, G., Wan, S., Zhou, J., Yang, Z., Qin, P., 2010 Leaf chlorophyll fluorescence, 
hyperspectral reflectance, pigments content, malondialdehyde and proline accumulation responses of castor bean (Ricinus communis L.) seedlings to salt stress levels. Industrial Crops and Products. 31: 13-19.

Lichtenthaler, K., Welburn, A.R., 1983. Determination of total carotenoids and chlorophylls $a$ and $b$ of leaf extracts in different solvents. Botanisches Institutder Univeristat, Kaiserstran $\beta$ e 12, Postfach pp. 591-592.

Mac Adam, J.W., Nelson, C.J., Sharp, R.E., 1992. Peroxidase activity in the leaf elongation zone of tall fescue. Plant Physiology. 99: 872-878.

Mohammadzadeh, M., Arouee, H., Neamati, S.H., Shoor, M., 2013. Effect of Different levels of Salt Stress and Salicylic Acid on Morphological Characteristics of four Mass Native Basils (Ocimum basilcum), International Journal of Agronomy and Plant Production. 4: 3590-3596.

Morales, C., Cusido, R.M., Palazon, J., Bonfill, M., 1993. Response of Digitalis purpurea plants to temporary salinity. Journal of Plant Nutrition. 16 (2): 327-335.

Mostofa, M.G., Fujita, M., Phan, Tran, L.S., 2015. Nitric oxide mediates hydrogen peroxideand salicylic acid induced salt tolerance in rice (Oryza sativa L.) seedlings, Plant Growth Regulation. 77:265-277.

Munns, R., 2003. Comparative physiology of salt and water stress. Plant Cell \& Environmental. 25: 239-50.

Nakano, Y., Asada, K., 1981. Hydrogen peroxide is scavenged by ascorbate specific peroxidase in spinach chloroplasts. Plant Cell Physiology. 22: 867-880.

Özgen, Y., Arslan, N., 2014. Ankara Şartlarında Bazı Reyhan (Ocimum basilicum L.) Hatlarının Tarımsal Özelliklerinin Belirlenmesi, II. Tıbbi ve Aromatik Bitkiler Sempozyumu. Yalova, s. 169- 173.
Parizi, M.D., Manouchehri Kalantari, K., Enteshari, S., Baghizadeh, A., 2011. Effect of salicylic acid and salt stress on $\mathrm{Na}$ and $\mathrm{K}$ content in Ocimum basilicum, Iranian Journal of Plant Physiology 1(3):133-139.

Qing, X., Zhao ,X., Hu, C., Wang, P., Zhang, Y., Zhang, X., Wang, P., Shi, H., Shi, H., Jia, F., Qu, C., 2015. Selenium alleviates chromium toxicity by preventing oxidative stress in cabbage (Brassica campestris L. ssp. Pekinensis) leaves. Ecotoxicology and Environmental Safety. 114: 179-189.

Qiu, Z., Guo, J., Zhu, A., Zhang, L., Zhang, M., 2014. Exogenous jasmonic acid can enhance tolerance of wheat seedlings to salt stress. Ecotoxicology and Environmental Safety. 104: 202-208.

Santos, C.V., 2004. Regulation of chlorophyll biosynthesis and degradation by salt stress in sunflower leaves. Scientia Horticulturae. 103: 93-99.

Tarchoune, I., Degl'Innicenti, E., Kaddour, R., Giidi, L., Lachaal, M., Navari-Izzo, F., Ouerghi, Z., 2012. Effects of $\mathrm{NaCl}$ or Na2SO4 Salinity on Plant Growth, Ion Content and Photosynthetic Activity in Ocimum basilicum L. Acta Physiologiae Plantarum 34(2):607-615.

Tarchoune, I., Sgherri, C., Izzo, R., Lachaal, M., Ouerghi, Z., Navari-Izzo, F., 2010. Antioxidative responses of Ocimum basilicum to sodium chloride or sodium sulphate salinization. Plant Physiology and Biochemistry 48: 772-777.

Telci, i., 2005. Reyhan (Ocimum basilicum L.) Genotiplerinde Uygun Biçim Yüksekliklerinin Belirlenmesi, Gazi Osmanpaşa Üniv. Ziraat Fak. Dergisi, 22 (2): 77- 83.

Wierdak, R.N., 2013. Morphological and chemical variability of Ocimum basilicum L. (Lamiaceae). Modern Phytomorphology. 3:115-118. 